should begin drinking sea water as soon as possible before dehydration starts but in small quantities only to avoid nausea and diarrhoea. Whatever fresh water is available should be carefully husbandod, and, if there is none, fluids should be expressed from fish by squeezing them in plastic bags or towels.

Bombard's experiments were followed by Dr. G. Aury, principal modical officer of the French Navy, who, in 1953 and 1954, earried out experiments on volunteers subjected to shipwreck conditions, he himself taking part. Aury described the experiments as boing successful; the sea water was readily drunk by the volunteers, they suffered from no werious complaints, and, when the experiments were over, they were able to resume their duties immediately. Tho experiments lasted only 2-4 days.

A German physician, Dr. Lindomann, mado no less than three voyages across the Atlantic ocean, in a canoe and thon in a collapsible boat. He reached diametrically opposite conclusions to those of Bombard and Aury. Sea water, he held, should nover be drunk; fluids could only be expressed from fish by means of a press; and no fish should bo eaten if no fresh water is available.

In 1959 the question of drinking sea watcr came beforo the Maritime Safety Committee of the InterGovernmental Maritime Consultativo Organization. The exporiments of Bombard and Aury, and the wide publicity they had received, created much confusion about the drinking of sea water, and the impression had spread that the dangers of drinking sea water had boen grossly oxaggerated. The Maritime Safoty Committee felt that an authoritative opinion was required on what had bocome a controversial quostion and asked the World Health Organization for its viows. Pending a firm opinion to the contrary, however, the Committes urged that no Governmonts should advocate the drinking of soa water by shipwrecked mariners.

The World Health Organization convened a meeting of five internationally recognized experts, Surgeon Captain F. W. Baskervillo (United Kingdom), Dr. J. Fabre (Switzerland), Dr. H. Laborit (Franco), Prof. R. A. MeCanco (United Kingdom) and Prof. A. V. Wolf (United States). They considered the offects of drinking sea water under three headings: effects on the bowel, on the body as a whole and on the mind*. Because of the well-known cathartic effects of salts, drinking sea water is likely to lead to intestinal discomfort, if not to frank diarrhoea. 'This effect varios in different individuals and is more likely to follow if large amounts are ingosted. On tho body as a whole, the offect of sea water is to overload the circulation with salt, which can only bo excreted by drawing on the body water and so dehydrating the body even more. If the salts are not excreted the effect will be equally harmful because of the increase in the concentration of salts in the body fluids. Finally, the evidence shows that even small amounts of sea water affect some individuals unfavourably, while large amounts havo been shown to lead to mental disturbances and even suicidal impulses.

Tho experts examined the contention that a limited supply of fresh water could be made to last longer if it were mixed with sea water. This has boen shown to bo feasible exporimentally in certain animals and is theoretically possible in man. But the group emphasized - no acceptable evidence has ever bcen adduced that in man sea water can be used satisfactorily to $e k \theta$ out supplies of fresh water. This as yct unproved hypothesis cannot, therefore, bo made the basis of a practical recommendation for saving the lives of people shipwrecked at sea.

One of the roasons for advocating the drinking of sea water is to preserve morale, which, in the circumstances of shipwreck, is likely to be low. The experts held the view that morale ean be maintained if it is made elear to the castaways that death from lack of water alone is scarcely possible for several days. It has been shown from experimental work that a man can remain reasonably fit without wator for six days, and mon have survived without it for twice that period at soa. It has also been shown that $500 \mathrm{ml}$. (one pint) of fresh water daily, if possible supplementod by $100 \mathrm{~g}\left(3 \frac{1}{2} \mathrm{oz}\right.$.) of carbohydrate, will maintain a man almost without deterioration for at least six days.

The group ended its report with advice to thoso who have to abandon ship, including the warnings to "Never drink sea water. Never mix sea water with fresh water if fresh water is in short supply. Sea water has been used to moisten the mouth, but the temptation to swallow it may bo irresistible and it is better not to use it for this purpose. Never drink urine".

*WHO Chronicle, 18, No. 9 (September 1062).

\title{
ECONOMIC LIFE OF CHEMICAL PROCESS PLANTS
}

"E CONOMIC Lifo of Process Plant" was the subject of a symposium held under the auspices of the Institution of Chemical Engineers in London on October 30. Obsolescence of chemical process equipment is a vital factor which has to be taken into account by the enginen responsiblo for dosigning chomical plants to operate at minimum cost over a reasonably predictable time, having regard to certain constraints governed by oporating conditions. The author of a paper on this subject, C. S. H. Munro, coneludes ". . . that the physical durability is by no means the only determining factor in tho life of chemical plant equipment and that the dosigner must consider vory carefully the future capacity requirements and the likelihood of procoss change". All requirements for capacity incroase of plant appoer. to ariso after periods of more than five years". . which is perhaps as long as any commercial ostimates might be considered valid". The argument would seem to indicate a case for increasing depreciationrates to accord with actual chemical plant life, which, as is well known in the industry, is one of the most difficult to assess compared with many othor engineering projects.

A mothod of determining economic optimum timing for replacing chomical plant was discussed by $H$. $R$. Fisher in his apparently new solution to this problem formulatod in Terborgh's Dynamio Equipment Policy (MeGraw-Hill Book Co., New York, 1949). H. C. D. Phillips, D. A. Petors and J. A. 
Hodson, of the Esso Petroleum Co., Ltd., Fawley, in a paper ". . . written against a background of experience in the design of refinery process plant", discussed the difficult matter of "Design Philosophy in the Economic Selection of Materials for Process Plants", including questions of selection of suitable materials of construction, also methods of calculation for carrying out economic evaluations. "The Economic Life of Chemical Plant in the Nuclear Fuel Industry" was considered by G. K. Dickson, K. J. Norman and R. R. Gunton of the U.K. Atomic Energy Authority. In the nuclear industry, established in Great Britain barely fifteen years ago, evolution has had the effect of transforming what was initially a national defence project to one based on normal commercial practice. They stated that "such a rapidly and drastically changing situation has required constant re-appraisal of the economic life of the plants involved".

"Process Plant in the Gas Industry" was the title of a paper given by C. Stott (S.E. Gas Board), emphasizing some of the problems of plant design for meeting 'base' and 'seasonal load' demands (under statutory obligation), and latterly the widespread adoption of oil gasification plant to meet such conditions and to replace outdated plant. The final paper, "The Economic Life and Size of Process Plant in Underdeveloped Countries", by A. P. Shahbenderian, demonstrated how ". . . it is possible to assess the economically optimum life and, in particular cases, the optimum capacity of chemical plant for situations where the market is static or the rate of growth predictable".
H. B. MuLNER

\section{THE TEASEL}

$I^{\mathrm{T}}$ $T$ is one of the minor mysteries of modern crop husbandry that teasel growing should have survived in a restricted area of south Somerset when it has died out in all the former teasel-growing areas of Britain. About four hundred acres are now grown. Formerly, teasels appear to have been widely grown. Arthur Young reported teasel beds in Essex, where they were cultivated in rotation with medicinal plants like coriander, and there were acreages in Wiltshire and Gloucestershire. When it was that the hookended bract of the teasel flower head was first used to comb up the pile on cloth is not known, but the process almost certainly originated in the West Country to give the characteristic hard-wearing nap to West-Country broadcloth. It is probable, too, that the husbandry of teasel-growing was either begun, or at least received its first impetus to expansion and improvement, from the influx and settlement of the Huguenot weavers.

The broadcloth industry in the hinterland towns which teasel-growers served is now largely dead, but an isolated area around the Somerset villages of North Curry, Curry Rivel and Fivehead remains devoted to teasel husbandry. This has been examined by John L. Jones, who describes how acreage fluctuates from two to three hundred and the number of farmers participating is about fifty (Land, 11; Autumn, 1961). For most of them it is a crop which has been grown on the family farm for generations.

Why, then, has it survived? Where a highly specialized crop survives, climate and soil must obviously be right, and the heavy loams and moderate rainfall of south Somerset suit the teasel. Another unique aspect of the soil is that much of the land is 'teart' in the region of the country distinguished by an excess of molybdenum, which expresses itself as a copper deficiency in cattle. This in itself may be a specific ecological factor of the teasel. More possibly, it was the economic aspect of teart land farming which may have contributed to the survival of teasel-growing. For until it was appreciated that the serious cattle sickness associated with teart land could be rectified with modern treatment, the farmers concerned would have been more interested to retain any lucrative cash crop for which their land was suited than those with sound and healthy land would have been to grow teasels. Added to this is the con- tinuity of husbandry and the skill and specialized knowledge acquired in centuries of growing.

The superiority of the teasel-the fuller's teasel, as it was formerly called-lies in the supple hookends of the bracts or awns of the cylindrical flower-heads. To-day all the Somerset teasels are bought for the northern cloth-finishing mills, where they are used to produce the brushed effect on the best-quality face cloths. For these the action of the finest wire brushes is too severe.

The teasel crop begins as a fine seed sown in drills in the spring. The early husbandry is as for roots, and the crop is hand-hoed to keep down weeds and afterwards singled out to 4 in. apart. By the end of autumn the plants are ready for transplanting-the teasel is a biennial-and lifted with a special tool called a 'spitter', which severs the long tap root. They are dibbled on to the ploughed furrow at a rate of twelve thousand plants to the acre. The convention is $30 \mathrm{in}$. between the rows and $24 \mathrm{in}$. between the plants. During this second year the plants throw out big central stems and side branches surmounted by prickly heads, which are ripe for the teaselling knife in August.

The teasel is one of the latest crops to receive the benefits of modern crop protection, which has considerably increased the yields from the fields of the more progressive growers. Squat malformed plants producing soft teasels with numerous 'dead head' plants as well had long been a mysterious problem in the Somerset teasel beds. Long field rests did nothing to help. Then the eel worm was isolated as a major teasel pest, which explained why resting between crops for long periods had not helped. The pest was being perpetuated in the soil by other crops such as oats, mangolds and beans, and on numbers of hedgerow hosts such as cleavers and chickweod. It was also being transmitted by infested seed, and teasel seed can now be pre-treated like clover to kill the pest. The growing crop may also need dusting against the teasel leaf miner-small egg-laying black-flies which hatch maggots on the leaves and cause bacterial rots. Not so easily handled, but rarely occurring, are attacks by the cucumber mosaic virus which causes leaf mottling and stunted growths, and the fungus of violet root rot, which destroys the tap root and starves the plant of nutriment. 